\title{
MONITORING PROPOSAL OF THE SPECIES VIOLET CARPENTER BEE XYLOCOPA VIOLACEA IN POLAND
}

Faculty of Animal Breeding, Bioengineering and Conservation, Warsaw University of Life Sciences SGGW, Poland

\begin{abstract}
The main purpose of this scientific publication is to present the suggested methods of monitoring the species violet carpenter bee Xylocopa violacea, which belongs to Hymenoptera of the bee family Apidae. Despite the fact that this insect is only partially protected under Polish national law, there are very few identified localities of these animals in Poland. The main problem related to the uncertainty of the number of the violet carpenter bee Xylocopa violacea is the lack of monitoring within national borders. The proposed method of population status assessment is based on the field research. These studies include the observations of many elements of the population and the environment and on predicting what are the prospects for protecting the violet carpenter bee Xylocopa violacea in Poland. The proposed method of population status assessment is based on the analysis of species presence and abundance and the proposed method of habitat status assessment is based on the analysis of area, food base, type of environment, elements of the habitat, the nature of the surroundings and habitat stability. The proposed methods can be also applied for Xylocopa valga, which can be easily confused with the violet carpenter bee Xylocopa violacea. What is the most important - regular monitoring may contribute to the recognition of other places of occurrence and will enable effective protection of the violet carpenter bee Xylocopa violacea in Poland.
\end{abstract}

Key words: monitoring methods, Xylocopa violacea, Apidae.

\section{INTRODUCTION}

The aim of this study is to propose methods of monitoring the species violet carpenter bee Xylocopa violacea due to noticeable shortcomings in this field.

\section{Description of species}

The violet carpenter bee Xylocopa violacea is a thermophilic species of bee, belonging to the solitary ones. Thus, it is one of the largest Polish Hymenoptera. It reaches 20 to $28 \mathrm{~mm}$ of body length - in comparison, the honeybee Apis mellifera worker measures about $12 \mathrm{~mm}$ (Dade 2009).

A characteristic sign of the violet carpenter bee Xylocopa violacea is its color. It has dark purple wings and a black abdomen, which is why it is commonly called a black bee. What is more, its body has a recognizable black and metallic glow and is covered with black hair.

Corresponding author: Maria Aleksa, Faculty of Animal Breeding, Bioengineering and Conservation, Warsaw University of Life Sciences - SGGW, Józefa Ciszewskiego 8, 02-786 Warszawa, Poland, e-mail: marysia.aleksa@op.pl 
Females can be distinguished from the male by the structure of antennae - female ones are composed of 12 parts, males - 13. Moreover, the female is characterized by a furrow-like frontal lobe and a pair of spines on the pygidial plate (Biwo and Olszanowska-Kuńka 2018).

The Xylocopa genus is one of the tribes belonging to the Xylocopinae. Among this subfamily of Hymenoptera, about 400 species can be distinguished, most of them are dark. In Poland, the violet carpenter bee Xylocopa violacea can only be confused with the Xylocopa valga. Phenotypically, these insects are very similar to each other. Females can be distinguished, among others, by a basitibial plate with a two-lobed tip and at most two series of strong teeth that occupy its entire front and rear edges. It is an organ located on the shin of the rear pair of legs, which function is not yet precisely defined. In males, however, the plate is not split, the tip of the shin has at least one notch noticeable from the dorsal side, while the back of the shin is covered with black hair. It can be distinguished from the male Xylocopa valga by its antennae with a rusty underside (11th and 12th segments). The antennae of male Xylocopa valga is completely black, with no brightening. In addition, the last part of the antennae from the Xylocopa violacea is pointed and rounded in the black horned bay, but it can only be observed under the binocular. What is more, the body length of the Xylocopa violacea most often varies between 21 and $24 \mathrm{~mm}$, while the Xylocopa valga body length ranges between 23 and $27 \mathrm{~mm}$ (Regner et al. 2016).

Megachile (Chalicodoma) parietina was another species similar to the violet carpenter bee Xylocopa violacea in Poland. Unfortunately, it is now considered as an extinct species.

\section{Biology of the species}

Insects of the genus Xylocopinae lead a solitary lifestyle for most of the year, which is why they are often called loners. They also breed individually. They build nests in dry, usually dead trees or their parts, such as fallen boughs or branches. Females dig straight corridors in them and build breeding cells there with the help of mandibles. The channels run horizontally at first and then run down sharply. Later, the female divides the canals with special valves made of compacted sawdust. As a result, the top of the first cell is also the bottom of the next. When the nest is ready, the insect flies out in search of pollen and nectar (even several kilometers away), which it delivers to each of the cells. After this preparation, the female lays one egg for each location, from which the larvae hatch. They feed on lumps left by their mother, pupate and overwinter in their cells. The female, on the other hand, does not fly away, but shows primitive social behavior - she stays in the vicinity of the nest to protect the growing or already adult offspring (Łoś et al. 2018).

Adults appear in May. They are most active in May and June. Then they can be observed throughout the summer, sometimes even until the end of October. They feed on many plants, most often they are observed on Fabaceae and Boraginaceae. Examples of plants on which these bees have been noticed are: The sweet pea Lathyrus odoratus, the black locust Robinia pseudoacacia and the viper's bugloss Echium vulgare (Dar et al. 2009).

\section{Habitat requirements}

The violet carpenter bee Xylocopa violacea is classified as a thermophilic species. It mainly inhabits steppe-like areas. It can also be observed in river valleys, at the edges of forests, on xerothermic and psammophilous grasslands, in orchards and gardens, in vineyards, 
as well as in flower meadows and fallow lands where they search for food. One of the reasons for the decline in the number of this species and its complete disappearance may be the decline of the steppe areas and the shortage of decaying old trees. These are the elements necessary for the development of the violet carpenter bee Xylocopa violacea (Vicidomini 2019).

\section{General remarks on geographical distribution}

Bees belonging to the Xylocopinae subfamily have a cosmopolitan range. However, they definitely prefer the tropical and subtropical countries. Their range extends from the Iberian Peninsula, through Turkmenistan, Tajikistan and Iran, to central China and northern India. In Europe, the greatest species diversity is observed in the Mediterranean basin, but there are species found in northern regions, such as in Finland, Sweden and Great Britain. Insects of this genus are presumed to have their origins in the Palearctic (Pawlikowski et al. 2018).

\section{Occurrence in Poland}

Representatives of the violet carpenter bee Xylocopa violacea species have their northern range limit in Poland. However, many individuals of this species have never been observed. Between the 1868 and 1935, only 8 position of occurrence were recorded. Moreover, in the first edition of the Polish "red list" this species was described as dying out. In the next edition, the situation changed, because this bee was considered probably extinct due to the fact that this bee has not been found in Poland for over 70 years. Currently, the violet carpenter bee Xylocopa violacea is only partially protected in Poland, as more and more specimens are recorded. This indicates that these bees have again become a component of the Polish entomofauna. In recent years, they have been observed at 6 sites: in the Poleski National Park, in the Małopolska Upland, in the Bieszczady Mountains, in Wrocław and in Lower Silesia in Oława. Moreover, new reproductive populations are observed, which inhabit new areas, which favors their dispersion and their population (Regner et al. 2016).

\section{CONCEPT OF THE SPECIES MONITORING}

\section{The aim of monitoring}

The violet carpenter bee Xylocopa violacea has been considered extinct in Poland for many years. However, in the 21st. century it has changed and more and more new localities of this species are observed. It is speculated that such a poor condition of the population of these animals from before that century may be caused, for example, by the lack of observations of this bee and its habitats. Due to this fact, active monitoring of the violet carpenter bee Xylocopa violacea should be introduced in Poland. It is necessary to take into account the sex and age of the bees, as well as conduct in vivo markings, focusing on the phenotype in order to prevent confusion with the related species of $X$. valga.

\section{The concept of monitoring}

The concept of monitoring works is based primarily on the field inventory of areas where individuals of this species have already been noticed, but also areas that have not yet been 
explored in this site, but belong to the range of these bees. In this case, monitoring works will consist observing the area and photographing individuals.

Species identification can also take place after the bees are caught with the use of an entomological net, which is used for the vital identification of individuals. After catching, clear pictures of the individual should be taken and it is best to determine the species and sex immediately (e.g. using a magnifying glass). After these treatments, the animal should be released immediately.

The areas where the species of the violet carpenter bee Xylocopa violacea have been marked should be included in the network of sites regularly monitored in Poland.

What is more, monitoring should cover all the steppe areas (habitats of Xylocopa violacea) in the south of Poland (according to the range of Xylocopa violacea) and large decaying stands in which these insects can nest. Thanks to this, it will be possible to evaluate the measures taken to improve the state of the violet carpenter bee Xylocopa violacea population in Poland.

Additionally, monitoring should cover areas within the possible occurrence of the violet carpenter bee Xylocopa violacea on which plants that are a food source of these bees are observed.

For the identification of specific species (to avoid confusion between Xylocopa violacea and Xylocopa valga) and gender, it is recommended to introduce the identification key, whose appearance proposed below (Table 1).

Table 1. An exemplary identification key for the determination of species from the genus Xylocopa in Poland (Pawlikowski et al. 2018)

\begin{tabular}{ll} 
X. violacea & $\begin{array}{l}\text { Body with a strong blue-metallic glow. The upper part of the head is rectangular. Rear shin } \\
\text { on the inside with a wide smooth field and small teeth on its surface }\end{array}$ \\
\hline$X$. valga & $\begin{array}{l}\text { Body with a faint blue-metallic glow. The upper part of the head is rounded. On the inside } \\
\text { of the rear shin with a narrow, smooth area and small teeth at the edges }\end{array}$ \\
\hline . violacea & $\begin{array}{l}\text { Body with a strong blue-metallic glow. Midsummer with black and gray hairs. The upper part } \\
\text { of the head is rectangular. 11-12 part of antennae reddish }\end{array}$ \\
$X$. valga & $\begin{array}{l}\text { Body with a faint blue-metallic glow. Midsummer with black hair. The upper part of the head } \\
\text { is rounded and all antennae are black }\end{array}$ \\
Female & $\begin{array}{l}\text { Head with 12-segment antennae. The abdomen consists of } 6 \text { segments, the last segment } \\
\text { is triangularly shaped }\end{array}$ \\
Male & $\begin{array}{l}\text { Head with 13-membered antennae. The abdomen consists of } 7 \text { segments, the last segment } \\
\text { is rounded }\end{array}$
\end{tabular}

Below is shown a photography (Fig. 1) of a specimen of the violet carpenter bee Xylocopa violacea, which was taken in 2021 in Germany. 


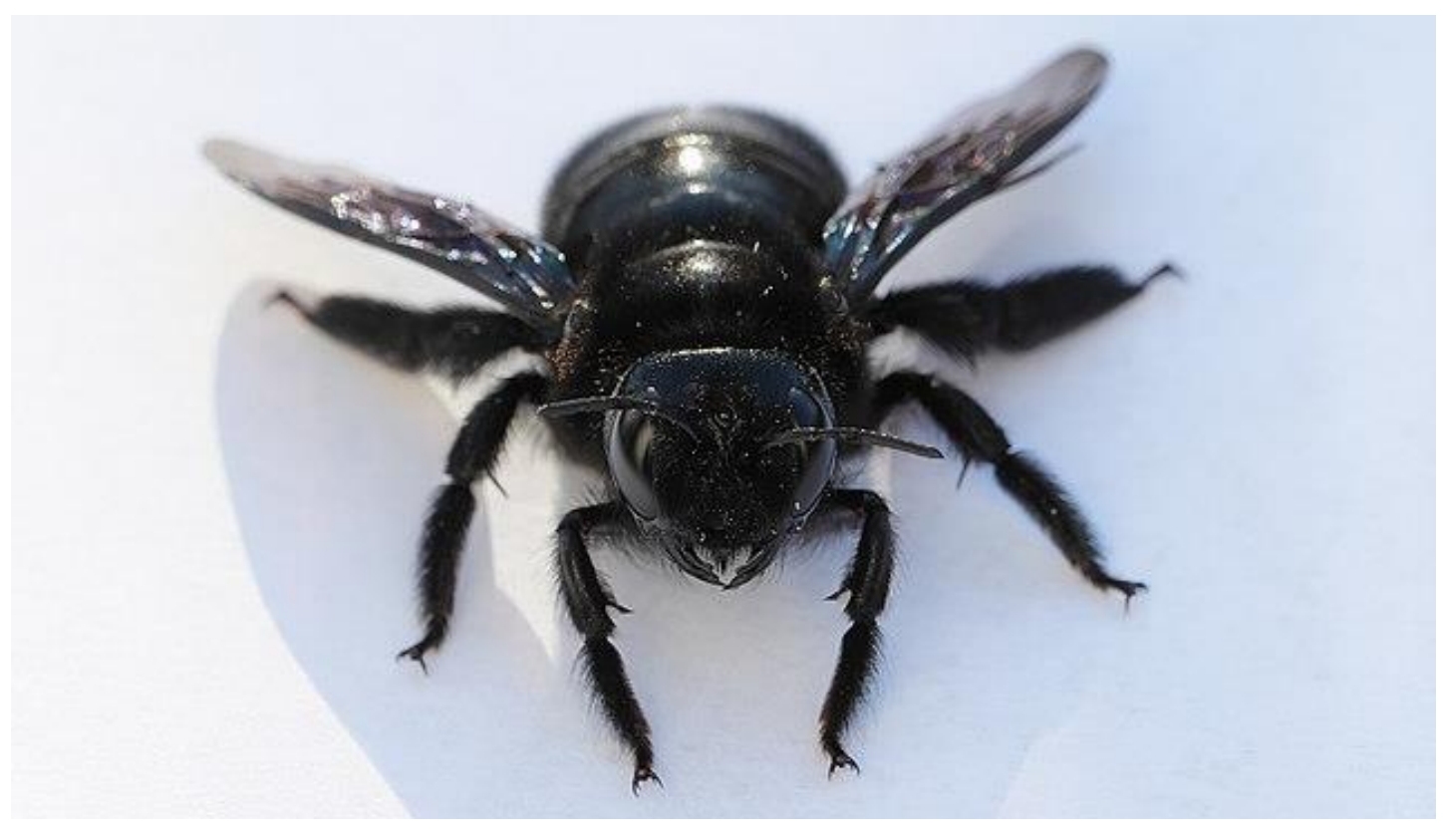

Fig. 1. The violet carpenter bee (Xylocopa violacea) photographed in February 2021 in Berlin (Bautsch 2021)

\section{INDICATORS}

Indicators of the population's state are shown in Table 2.

Table 2. Indicators of the state of population of the violet carpenter bee Xylocopa violacea

\begin{tabular}{lll}
\hline Indicator & Measurement & Way of evaluation \\
\hline Species presence & there is / is not & $\begin{array}{l}\text { Verification of the occurrence of the violet carpenter bee } \\
\text { Xylocopa violacea in any life stage in a specific position }\end{array}$ \\
\hline
\end{tabular}

Due to the fact that previously no monitoring of the violet carpenter bee Xylocopa violacea was carried out in Poland and the lack of knowledge about the parameters of the population of this bee occurring in the past in the domestic area of the species, it is impossible to valorize the population status indicators based on the number of individuals. Only presence of the species will be taken into account in the evaluation.

Adopted valorization of the status indicators of the population is presented in Table 3.

Table 3. Proposed valorization of the population status indicator on the scale of the biogeographic region

\begin{tabular}{ccccc}
\hline Parameter & Indicator & \multicolumn{3}{c}{ Evaluation } \\
\cline { 3 - 4 } Population & species presence & FV & U1 & U2 \\
\hline & $\begin{array}{c}>60 \% \text { of } \\
\text { monitoring } \\
\text { positions }\end{array}$ & $\begin{array}{c}>30 \% \text { of } \\
\text { monitoring } \\
\text { positions }\end{array}$ & $>10 \%$ of monitoring \\
positions
\end{tabular}

FV - proper condition, U1 - condition unsatisfactory, U2 - bad condition. 


\section{Evaluation of the state of the population}

The evaluation of the population status should be performed on the basis of the evaluation for both of the above-mentioned indicators - species presence and abundance. Thanks to many reports from the monitoring, it will be possible to compare different areas with the violet carpenter bee Xylocopa violacea. Finally, it will be possible to determine what number of these bees should be occurring in the selected transect.

The evaluation of the population status is determined on the basis of the species presence indicator in such a way that point values are assigned to them: FV -2 points, U1 - 1 point, U2 - 0 points, then the points are summed up and referred to the scale.

Indicators of the habitat are shown in Table 4.

Table 4. Indicators of the habitat of the violet carpenter bee Xylocopa violacea

\begin{tabular}{lll}
\hline Indicator & \multicolumn{1}{c}{ Measurement } & \multicolumn{1}{c}{ Way of evaluation } \\
\hline Area & \multicolumn{1}{c}{ ha } & $\begin{array}{l}\text { Determination of the area inhabited by the species in the field } \\
\text { using GPS or current map }\end{array}$ \\
\hline Food base & $\begin{array}{l}\text { Determination of potential and used plants by the Xylocopa } \\
\text { violacea imago and a relative estimate (\%) of land cover with } \\
\text { these plants }\end{array}$ \\
\hline Type of environment & $\begin{array}{l}\text { descriptive } \\
\text { assessment }\end{array}$ & $\begin{array}{l}\text { Indication of the type of habitat where the species has been } \\
\text { found }\end{array}$ \\
\hline Elements of the habitat & $\begin{array}{l}\text { the number of } \\
\text { elements/ position }\end{array}$ & $\begin{array}{l}\text { Indication of the elements of the habitat used by the Xylocopa } \\
\text { violacea in the construction of nests along with their number }\end{array}$ \\
\hline $\begin{array}{l}\text { The nature of the } \\
\text { surroundings }\end{array}$ & $\begin{array}{l}\text { descriptive } \\
\text { assessment }\end{array}$ & $\begin{array}{l}\text { Identifying the elements of the environment that may positively } \\
\text { species }\end{array}$ \\
\hline Habitat stability & $\begin{array}{l}\text { descriptive } \\
\text { assessment }\end{array}$ & $\begin{array}{l}\text { Overall assessment of the site in terms of its constancy / } \\
\text { possible transformations }\end{array}$ \\
\hline
\end{tabular}

Due to the fact that the violet carpenter bee Xylocopa violacea was not previously monitored in Poland and due to the lack of knowledge about the parameters of the habitats of the population present in the national area of the species in the past, the valorization is very limited. The only indicator that can be assessed as the elements of the habitat is dry or rotting wood on trunks or branches, which are an essential part of the violet carpenter bee Xylocopa violacea environment. Their presence will classify the habitat as favorable for the presence of bees in the inventoried area, their absence, the other way.

\section{Cardinal indicators}

Dry or rotting wood in trunks or branches.

Females of the violet carpenter bee Xylocopa violacea make nests in them and then lay their eggs there. Without them, reproductive success may be inhibited, therefore it is an essential element for the life of these bees.

Adopted valorization of the habitat indicators of the population is presented in Table 5. 
Table 5. Proposed valorization of the habitat indicator on the scale of the biogeographic region

\begin{tabular}{lccc}
\hline \multirow{2}{*}{ Indicator } & \multicolumn{3}{c}{ Evaluation } \\
\cline { 2 - 4 } & $\mathrm{FV}$ & $\mathrm{U} 1$ & $\mathrm{U} 2$ \\
\hline $\begin{array}{l}\text { Elements of the } \\
\text { habitat }\end{array}$ & many & sparse & no elements \\
\hline
\end{tabular}

Elements of the habitat: Dry or rotting wood in trunks or branches.

FV - proper condition, U1 - condition unsatisfactory, U2 - bad condition.

\section{Evaluation of the habitat condition}

The key indicator is the elements of the habitat that determine other indicators, including population status indicators.

The evaluation of the habitat condition is determined on the basis of the evaluation of the habitat element index in such a way that point values are assigned to them: FV - 2 points, U1 - 1 point, U2 - 0 points, then the points are summed up and referred to the scale.

All other indicators, including those with a descriptive assessment, are also taken into account. They describe the habitat of the violet carpenter bee Xylocopa violacea. However, it is possible to modify. When an apparently negative indicator for bees has been distinguished, but apparently does not affect the state of the population, or even the population develops well in its presence, then such an indicator may be omitted in the overall assessment.

\section{PROTECTION PERSPECTIVES}

The evaluation of the protection perspectives should be based on the evaluation of the population and habitat status, taking into account the diagnosed current and anticipated threats. In particular, the likelihood of the disappearance of more stands that provide bees with places to build their nests should be considered. Active protection of such elements of the habitat should be introduced in such situation.

- FV - very good or good prospects; it is expected that the current favorable condition of the population and habitat will be maintained or improved, e.g. as a result of the implementation of appropriate protective measures at a given site;

- U1 - average prospects; the current favorable conservation status may deteriorate or, in the expert's opinion, the unsatisfactory condition will persist in the following years due to the lack of appropriate active protection measures;

- U2 - bad prospects; the current poor state of preservation will persist, or due to the lack of appropriate protective measures, a serious deterioration of the population and habitat is expected.

\section{GENERAL EWALUATION}

The general evaluation should include: population evaluation, habitat evaluation and the conservation perspective of the species. However, due to the current lack of knowledge to predict the state of the violet carpenter bee Xylocopa violacea in Poland, the indicator of the species protection perspectives can be omitted. At the moment, the focus should be on regular monitoring in order to create the most abundant database with information about the population and habitats of the bay violet. Of these two indicators, the lowest of the sub-grades should be selected for an overall grade. 


\section{MATERIAL AND METHODS}

\section{Selection of monitoring areas and their suggested size}

In the case of the violet carpenter bee Xylocopa violacea, due to its rarity and scarcity of observations, monitoring should cover each of the previously mentioned positions - entire. What is more, due to the observed spread of this species to new areas, the areas favorable to the occurrence of this bees and located in its northern range should also be monitored.

The current priority should be to conduct a large-scale search for other relict or new sites of the species and, if found, include them in the national monitoring network.

The sites should be at least 100 meters wide, but this value may vary depending on environmental resources.

\section{The method of carrying out the research}

The first step in performing the research should be the designation of sites where the research will be carried out with the specified indicators. The next one will be preparing the equipment necessary for monitoring and appearing at the chosen position. Field observations should be carried out according to recommendations in the spring-autumn period. After observation, the monitoring cards should be completed and interpreted. Finally, the condition of the species and its habitat should be assessed.

\section{Determining population status indicators}

Species presence. In order to determine whether the violet carpenter bee Xylocopa violacea species is present at a given location, it is recommended not only to set color traps for catching wild bees, but also to observe the surroundings, especially in the steppe-like areas. It is equally important to monitor flowering legumes and borage plants from which bees obtain pollen and nectar. It is also worth searching for potential microhabitats for the development of the violet carpenter bee Xylocopa violacea, such as dead, dry trees, in which these insects may nest.

All found specimens should be marked, described and photographed.

Abundance. This indicator informs about the number of individuals in a given position. First, the number of bees per 100 meters is examined. In order to achieve the final result, the average of all the measurements is taken. At the moment, it is not possible to refer to the results due to the lack of data on the density of the violet carpenter bee Xylocopa violacea, but it is the basis for future monitoring of this species.

\section{Determining habitat status indicators}

Area. This indicator informs about the number of hectares of the violet carpenter bee Xylocopa violacea in relation to the examined location. This indicator will inform about the possibility of this species flying over longer distances, and thus its probable dispersion. Thanks to this, it will be possible to designate further monitoring stations.

Food base. This indicator signifies the presence of potential plants that are fed by the violet carpenter bee Xylocopa violacea. At the same time, their relative numbers in the designated position should be specified. By the way, it is worth writing down which plants the bee was most often noticed on. Moreover, the indicator assumes giving approximately what \% of the examined location is covered with plants preferred by the tested bee species. The value from $0-10 \%$ means poor food base, $10-25 \%$ - average, $25-100 \%$ - rich. 
Type of environment. Information on the type of habitat in which the species was observed should be provided. One should pay attention to anthropopressure (that should be also marked in the description). It should be assessed whether the environment is favorable for the occurrence of the violet carpenter bee Xylocopa violacea, is moderately favorable, or unsuitable for this species despite the observation of individuals in the area.

Elements of the habitat. This indicator includes the necessary dead, dry wood for the violet carpenter bee Xylocopa violacea, in which it can tunnel and lay eggs. Their number for a given position is important. In the case of $>5$ it is a very good condition, of $>1$ it is an acceptable condition, and in the case of none, it is a bad condition. In this indicator, the places adjacent to the research position are also observed in order to find dead wood, which located within sight may be considered as determinable in this location.

The nature of the surroundings. This indicator informs about what the environment is being used for. Due to the fact that the violet carpenter bee Xylocopa violacea is a rare species and is often classified as a wild bee, the best areas for it will be natural, with zero human activity. On the other hand, areas intensively used by humans will constitute as worse habitat for this species.

Habitat stability. This indicator informs about the spatial and temporal continuity of the elements of the environment at a given position. Not only changes caused by human activity are assessed here, but also succession, land flooding and the presence of many types of natural habitats in one area.

\section{Time and frequency of field research}

Due to the qualitative nature of the monitoring, which consists verifying the presence of specimens of the violet carpenter bee Xylocopa violacea in adult form, the research can be carried out from May, i.e. from the beginning of flying of these bees, until the end of October, i.e. depending on the weather conditions, until the last month, in which these insects are observed. The observations conducted so far show that the violet carpenter bee Xylocopa violacea is most active at the turn of spring and summer - in May and June. Then the observations should take place with the greatest frequency.

Taking into account the fact that new positions of the violet carpenter bee Xylocopa violacea are observed every year, its monitoring should be carried out every year.

\section{Research equipment and materials}

1. A device with a GPS receiver to mark the places of occurrence of the species.

2. Current maps with marked boundaries of the given locations.

3. A camera with a macro lens.

4. Color traps.

5. Entomological net for catching and vital identification of specimens.

6. Magnifier (12-20x).

7. Pencil, pen.

8. Working species observation cards or notebook.

9. Atlas of plants for the correct identification these preferred by the violet carpenter bee Xylocopa violacea (optional).

10. An exemplary field key for the correct identification of species from the subfamily of the Xylocopinae in Poland. 


\section{Species with similar ecological requirements for which the presented methodology can be adapted}

The presented methodology can be adapted to the Xylocopa valga, a species almost identical phenotypically and behaviorally to the violet carpenter bee Xylocopa violacea. It is also rarely noted in Poland, and additionally it is under strict protection in the country.

\section{SAMPLE OBSERVATION CARD FILLING}

As part of the monitoring, the table with the method of estimating the conservation status of the species on the site was also proposed, as it is presented in the Table 6.

Table 6. Sample card filling with conservation status of the species at the site

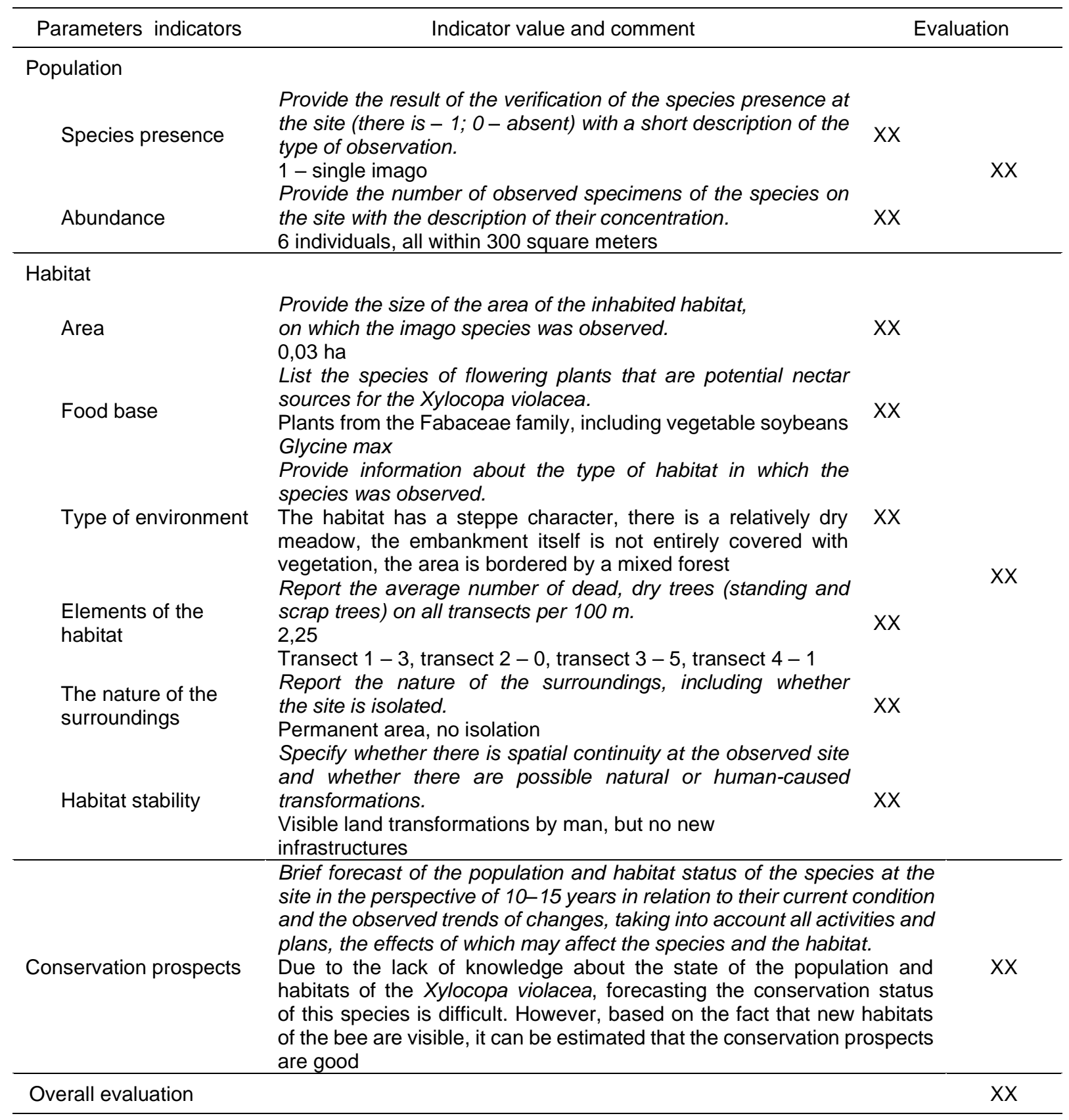

FV - proper condition, U1 - condition unsatisfactory, U2 - bad condition, XX - state unknown. 
Monitoring cards should also contain such documents as: current impacts card, threats card and a card with additional information. These are presented in the Tables 7-9.

Table 7. Current impacts card

\begin{tabular}{llccl}
\hline Code & The name of the activity & Intensity & Influence & \multicolumn{1}{c}{ Synthetic description } \\
\hline G05.07 & $\begin{array}{l}\text { Improperly implemented pro- } \\
\text { tective measures or the lack } \\
\text { of them }\end{array}$ & 1 & $-\begin{array}{l}\text { No protective measures aimed } \\
\text { at preserving the habitats of the } \\
\text { Xylocopa violacea. } \\
\text { No monitoring }\end{array}$ \\
\hline A03.02 & Non-intensive mowing & 1 & $+\begin{array}{l}\text { This may have a positive impact on } \\
\text { the inhibition of succession and not } \\
\text { overgrowing steppe-like areas }\end{array}$ \\
\hline
\end{tabular}

* Intensity: A - strong, B - medium, C - weak

" Impact: "-" - negative, "+" - positive, "0" - neutral

Table 8. Threats card

\begin{tabular}{|c|c|c|c|c|}
\hline Code & The name of the activity & Intensity & Influence & Synthetic description \\
\hline K02.01 & $\begin{array}{l}\text { Change of species } \\
\text { composition (succession) }\end{array}$ & C & - & $\begin{array}{l}\text { The disappearance of plants used } \\
\text { by Xylocopa violacea in favor of } \\
\text { other plants unsuitable for these } \\
\text { insects }\end{array}$ \\
\hline$E$ & $\begin{array}{l}\text { Urbanization, housing and } \\
\text { commercial construction }\end{array}$ & $A$ & - & $\begin{array}{l}\text { Unfavorable transformation of the } \\
\text { natural habitats of the Xylocopa } \\
\text { violacea or their complete dis- } \\
\text { appearance caused by human } \\
\text { activity }\end{array}$ \\
\hline B01 & Afforestation the open lands & C & - & $\begin{array}{l}\text { Afforestation the potential habitats } \\
\text { of Xylocopa violacea, or those } \\
\text { where it is already present }\end{array}$ \\
\hline B02.04 & $\begin{array}{l}\text { Removing the dead } \\
\text { and dying trees }\end{array}$ & $B$ & - & $\begin{array}{l}\text { Removal of potential nesting sites } \\
\text { for Xylocopa violacea }\end{array}$ \\
\hline
\end{tabular}

* Intensity: A - strong, B - medium, C - weak

* Impact: "-" - negative, "+" - positive, "0" - neutral

Table 9. Additional information card

\begin{tabular}{ll}
\hline Other natural values & $\begin{array}{l}\text { Other species of animals and plants observed during the monitoring works which are } \\
\text { listed as endangered from various appendices. } \\
\text { Bombus terrestris }\end{array}$ \\
\hline $\begin{array}{l}\text { Alien and invasive } \\
\text { species }\end{array}$ & $\begin{array}{l}\text { Observed alien and invasive species. } \\
\text { None }\end{array}$ \\
\hline $\begin{array}{l}\text { Methodical } \\
\text { comments }\end{array}$ & $\begin{array}{l}\text { Any other comments related to the work carried out. Including, in particular, information } \\
\text { important for further monitoring planning (work methodology, indicators that should be } \\
\text { tested in monitoring, regionally optimal research time, etc.). } \\
\text { Mowing meadows }\end{array}$ \\
\hline $\begin{array}{l}\text { Other comments / } \\
\text { other observations }\end{array}$ & $\begin{array}{l}\text { Any information helpful in the interpretation of the results, e.g. weather conditions, high } \\
\text { water level, recent changes in the site (what and when did they occur?), Etc. } \\
\text { 24 degrees Celsius, full sun }\end{array}$ \\
\hline $\begin{array}{l}\text { Photographic } \\
\text { and cartographic } \\
\text { documentation }\end{array}$ & $\begin{array}{l}\text { Attachments to the database (in electronic version): At least 2 photos per site (species, } \\
\text { habitat), boundaries of the research area marked on the appropriate cartographic } \\
\text { background }\end{array}$ \\
\hline
\end{tabular}




\section{CONCLUSIONS}

\section{Species protection}

Due to the limited amount of data available on the violet carpenter bee Xylocopa violacea, it is impossible to define precise methods of protection. It is difficult to predict what effect the various observed changes already have or will have on the population of this species in the future. Therefore, constant monitoring should be of key importance.

In the long-term plan, a thorough search for the violet carpenter bee Xylocopa violacea should be carried out in potential places of occurrence, i.e. throughout southern Poland along the border of this species' occurrence. The found positions should be included in the systemic protective measures, which should provide:

- limiting or completely abandoning the removal of dead standing trees and dead, dry, fallen tree elements, such as trunks and branches, where this species was found;

- ensuring the durability of the steppe areas in the area where the species was found;

- ensuring the durability of the occurrence of plant species constituting a source of nectar for the monitoring species;

- striving to expand the occurrence sites and range of the purple ridgeback through protection of their habitats and constant monitoring.

\section{REFERENCES}

Banaszek J., Banaszek-Cibicka W., Twerd L. 2019. Possible expansion of the range of Xylocopa violacea L. (Hymenoptera, Apiformes, Apidae) in Europe. Turk. J. Zool. 43, 650-656.

Banaszek-Cibicka W.A. 2006. Zagrożenia i ochrona prawna wybranych gatunków dziko żyjących pszczół (Hymenoptera: Apoidea: Apiformes) [Threats and protection by low of wild bees (Hymenoptera: Apoidea: Apiformes)]. Wiad. Entomol. 25(2), 17-20. [in Polish]

Biwo T., Olszanowska-Kuńka K. 2018. Potwierdzenie występowania zadrzechni fioletowej Xylocopa violacea (Linnaeus, 1758) (Hymenoptera: Apidae) na Opolszczyźnie [The confirmation of Xylocopa violacea (Linnaeus, 1758) (Hymenoptera: Apiformes) presence in Wroclaw city area]. Fragm. Nat. 51, 1-5. [in Polish]

Dade H.A. 2009. Anatomy and dissection of the Honeybee. Cardif, International Bee Research Association, 30-56.

Dar S.A, Mir G.M., Parry M.A., Sofi M.A., Padder S.A. 2016. Nest distribution and nesting habits of Xylocopa violacea (Donovan), Fabricius (Hymenoptera: Apidae) in Kashmir Valley. J. Exp. Zool. India 19(1), 155-162.

Łoś A., Schulz M., Ścibior R., Strachecka A. 2018. Nowe stanowiska zadrzechni (Xylocopa spp.) (Hymenoptera: Apidae) we wschodniej Polsce [New localities of carpenter bees (Xylocopa spp.) (Hymenoptera: Apidae) in Eastern Poland]. Nauki Przyr. 2(20), 59-63. [in Polish]

Pawlikowski T., Olszewski P., Sikora A., Przybylińska M. 2018. Dyspersja pszczoły zadrzechni fioletowej Xylocopa violacea (Hymenoptera: Apidae) w Polsce [Dispersion of the carpenter bee Xylocopa violacea (Hymenoptera: Apidae) in Poland]. Chrońmy Przyr. Ojcz. 74(3), 220-223. [in Polish]

Regner J., Smolis A., Kadej M. 2016. Zadrzechnia fioletowa Xylocopa violacea (Linnaeus, 1758) na Dolnym Śląsku - kolejne stwierdzenie w XXI wieku [The violet carpenter bee Xylocopa violacea (Linnaeus, 1758) in Lower Silesia - the next record in the 21st century]. Przyr. Sud. 19, 83-86. [in Polish]

Twerd L., Banaszek J. 2017. Monitoring dzikich pszczół w nieużytkach poprzemysłowych na Kujawach [Monitoring of wild bees in postindustrial wastelands in the Kujawy region]. Inż. Ekol. 18(2), 180-188. [in Polish] 
Vicidomini S. 2009. Biology of Xylocopa violacea (Hymenoptera): In-nest ethology. Ital. J. Zool. 63(3), 237-242.

\section{PROPOZYCJA MONITORINGU GATUNKU XYLOCOPA VIOLACEA W POLSCE}

Streszczenie. Głównym celem pracy było przedstawienie sugerowanych metod monitoringu gatunku zadrzechni fioletowej Xylocopa violacea, należącego do rzędu błonkoskrzydłych Hymenoptera z rodziny pszczołowatych Apidae. Mimo że owad ten jest jedynie częściowo chroniony prawem krajowym, w Polsce zidentyfikowane są nieliczne jego stanowiska. Główny problem z tym związany polega na tym, że w obrębie państwa nie jest prowadzony czynny monitoring tych owadów. Zaproponowana metoda oceny stanu zadrzechni fioletowej w Polsce zawiera badania terenowe. Ocena stanu populacji opiera się na analizie obecności i liczebności gatunku, a zaproponowana metoda oceny stanu siedlisk opiera się na analizie wielu innych czynników, takich jak: powierzchnia, baza pokarmowa oraz siedlisko. Proponowane metody można zastosować również dla zadrzechni czarnorogiej Xylocopa valga, która może być łatwo mylona z zadrzechnią fioletową. Co najważniejsze, regularny monitoring może przyczynić się do rozpoznania innych miejsc występowania i umożliwić skuteczną ochronę zadrzechni fioletowej w Polsce.

Słowa kluczowe: metody monitoringu, zadrzechnia fioletowa, pszczołowate. 
